\title{
Metaphysical Reasons for Choice between Three Kinds of Emergency Contraception
}

\author{
Andrzej Brodziak ${ }^{1 *}$, Agnieszka Wolińska² and Alicja Różyk-Myrta² \\ ${ }^{1}$ Institute of Occupational Medicine and Environmental Health, Poland \\ ${ }^{2}$ Institute of Nursing, University of Applied Sciences, Poland \\ Submission: May 10, 2017; Published: May 30, 2017
}

*Corresponding author: Andrzej Brodziak, Institute of Occupational Medicine and Environmental Health, Koscielna 13, 41-200 Sosnowiec, Poland, Tel: +48605044609, Email: andrzejbrodziak@wp.pl

Keywords: Emergency contraception; Public health; Legislation; Philosophy; Abortion; Conscientious objection

\section{Introduction}

Willetts et al. [1] presented recently in the paper "A survey regarding acceptability of oral emergency contraception according to the posited mechanism of action", interesting, rarely analyzed considerations on the different attitudes of women towards EC pills inhibiting ovulation, or preventing implantation or disrupting implantation [1].

The conducted survey demonstrated only slight differences in the proportions of opinions in the groups of examined women. The cited authors wrote: "women reported that EC would be acceptable if it worked by inhibiting ovulation (89\%), preventing implantation (83\%) or disrupting implantation (75\%)".

The questionnaire was distributed among particular, chosen groups of women:

(a) Presenting for EC at a community pharmacy,

(b) Attending a clinic for insertion of intrauterine contraception (IUC) or

(c) Attending a clinic for an induced abortion.

\section{Intercalation of philosophy to the medical practice}

It can happen, however, that the opinion about the acceptability of EC "according to the posited mechanism of action" is dramatically different when we are dealing with representatives of conservative, fundamentalist worldview factions.

It is possible to provide a meaningful example. The current Minister of Health of the present Polish government on February 2017 forbade pharmacists to sell over the counter the pill containing ulipristal acetate [2]. What is more, after a few days he gave an interview and stated that he as a physician would not prescribe a "day after pill", even to a raped woman, and even if she were his daughter [3].

It seems to us that for the sake of public health, such convictions as well the differences in the proportions of attitudes towards three kinds of EC demonstrated by Willetts et al. [1] should be comprehended.

These convictions probably arise from different philosophical views of the essence of the fertilized egg. This topic is more thoroughly discussed in the realm of considerations related to the admissibility of abortion.

It turns out that the opponents of abortion are not able to find appropriate justifications in the original records of religious dogma.

The unique mention of abortion in the Old Testament is the following passage 21:22 of the Book of Exodus: (21: 22. If people are fighting and hit a pregnant woman and she gives birth prematurely but there is no serious injury, the offender must be fined whatever the woman's husband demands and the court allows. 23. But if there is serious injury, you are to take life for life, 24. Eye for eye, tooth for tooth, hand for hand, foot for foot)

So, the arguments of pro-life proponents are based on the changing opinions of the hierarchy of the church, which has transformed over the centuries. It appears that these arguments are based on the speculative considerations of Thomas Aquinas [4]. The disputes of theologians have been undertaken by contemporary professional philosophers $[5,6]$. 
The proponents of Thomas Aquinas' concepts assume that the human being is composed of the body and an immaterial substance. The immaterial substance is called also the soul, nevertheless, it is not located in the brain only. This way of understanding dualism, called the "substance view", focus on continuation of the existence of the human being since its beginning. Beckwith discusses the cases of anencephalic children and argues that the essence of a person is not necessarily bound with the brain [5]. Nathan Nobis comprehensively and rigorously discusses Beckwith's argument [6].

He emphasizes that the substance view claims that fetuses and adults are the same "type" of being, the same "substance" and so "fetuses and adults are numerically identical". The substance view denies the connection of the essence of human being with the activity and integrative role of the nervous system and developing self-awareness.

Thus, persons forming the legislation regulating the distribution of EC, as well as some women who choose these substances, attach great importance to whether the considered substance suppresses ovulation and therefore prevents fertilization or rather prevent the implantation of the fertilized egg cell. Levonorgestrel posses the first property [7].

Ulipristal acetate apart of suppression of ovulation, prevent also the implantation of the fertilized egg [8].

According to imagination of people recognizing the described "substance view" of the essence of human personhood the prevention of the implantation of the fertilized egg causes the "kiling of a person".

\section{Conclusion}

It should be therefore stated that among people, often men, but entangled in ideological disputes, one may encounter intense evaluation of "the acceptability of EC according to the posited mechanism of action".
People, who are proponents of so called pro-life attitude, believe that the EC, which consists on prevention of implantation of the fertilized egg (as pills containing ulipristal acetate), is "equivalent of the killing of a person", The application of the pill containing eg. levonorgestrel, which inhibit ovulation, in eyes of these persons, is a permissible measure although is less effective because it does not prevent unwanted pregnancy when taken after ovulation.

This dispute is an example of the stirring influence of speculative inference, related to the specific concept of the soul, which cannot be verified - upon the admissibility of the indicated methods of medical procedures.

\section{References}

1. Willetts SJ, MacDougall M, Cameron ST (2017) A survey regarding acceptability of oral emergency contraception according to the posited mechanism of action. Contraception pii: S0010-7824(17)30100-2.

2. Bochenek R (2017) That's for sure "Day after" tablets will be only on prescription in Polish, Gazeta.

3. Alicja Dusza (2017) The minister would not have prescribed a "day after" pill even to a raped woman - "I have the right to do that"Minister said in Polish.

4. Robinson BA (2017) Roman Catholicism and abortion access, Pagan \& Christian beliefs 400 BCE -1983 CE. Ontario Consultant's on Religious Tolerance.

5. Beckwith FJ (2005) Of souls, selves, and cerebrums: a reply to Himma. J Med Ethics 31 (1): 56-60.

6. Nobis N (2011) Abortion, metaphysics and morality: a review of Francis Beckwith's Defending life: a moral and legal case against abortion choice. J Med Philos 36(3): 261-273.

7. Noé G, Croxatto HB, Salvatierra AM, Reyes V, Villarroel C, Muñoz C, et al. (2011) Contraceptive efficacy of emergency contraception with levonorgestrel given before or after ovulation. Contraception 84(5): 486-492.

8. Mozzanega B, Gizzo S, Di Gangi S, Cosmi E, Nardelli GB, et al. (2014) Ulipristal acetate: critical review about endometrial and ovulatory effects in emergency contraception. Reprod Sci 21(6): 678-685.

\section{Your next submission with Juniper Publishers will reach you the below assets}

- Quality Editorial service

- Swift Peer Review

- Reprints availability

- E-prints Service

- Manuscript Podcast for convenient understanding

- Global attainment for your research

- Manuscript accessibility in different formats

( Pdf, E-pub, Full Text, Audio)

- Unceasing customer service

Track the below URL for one-step submission https://juniperpublishers.com/online-submission.php 